\title{
ANALISIS HASIL BELAJAR FISIKA DI SMA NEGERI 3 MAKASSAR
}

Mafudiansyah*

Universitas Negeri Makassar mahfudiansyah@gmail.com

Salamang Salmiah Sari Universitas Negeri Makassar

Salmiahsari@unm.ac.id

Muhammad Arsyad Universitas Negeri Makassar MuhArsyad@unm.ac.id

*koresponden author
Abstrak - Penelitian ini menggunakan metode deskriptif dengan pendekatan kuantitatif yang bertujuan untuk menganalisis informasi tentang deskripsi hasil belajar fisika di SMA Negeri 3 Makassar tahun ajaran 2018/2019. Subyek dalam penelitian ini adalah peserta didik kelas XI MIA 3 SMA Negeri 3 Makassar yang berjumlah 30 peserta didik. Untuk memperoleh data hasil belajar psikomotorik peserta didik maka digunakan lembar observasi dan untuk memperoleh data hasil belajar kognitif peserta didik maka pada akhir pembelajaran dilakukan tes akhir dengan menggunakan instrumen tes soal bentuk pilihan ganda. Berdasarkan analisis statistik deskriptif diperoleh bahwa nilai rata-rata hasil belajar kognititf peserta didik sebesar 13,97 dengan standar deviasi sebesar 4,29 atau berada pada kategori sedang. Nilai rata-rata hasil belajar psikomotorik peserta didik sebesar 16,46 dengan standar deviasi sebesar 1,63 atau berada pada kategori tinggi.

Kata Kunci : Analisis, Penelitian Deskriptif, Hasil Belajar Kognitif, Hasil Belajar Psikomotorik

\begin{abstract}
This research used descriptive method by discussing quantitative which aims to analyze information about the description of physics learning outcomes at SMAN 3 Makassar. The subjects in this study were students of class XI MIA 3 of SMAN 3 Makassar amounting to 30 students. To find out the scores on the psychomotor learning outcomes of students, the observation sheet was used and to find out the scores on the cognitive learning outcomes of the students, at the end of the lesson they were given a final test using multiple choice questions. Based on descriptive statistical analysis obtained from the average value of cognitive learning outcomes of students amounting to 13.97 with a standard deviation of 4,29 or in the medium category. The average psychomotor learning outcomes of students amounted to 16.46 with a standard deviation of 1,63 or in the high category.
\end{abstract}

Keywords : Analysis, Descriptive Research, Cognitive Learning Outcomes, Psychomotor Learning Outcomes 


\section{A. PENDAhuluAN}

Pendidikan merupakan salah satu program pemerintah yang diselenggarakan secara berkesinambungan untuk mengembangkan segala potensi-potensi masyarakat dalam rangka mempersiapkan sumber daya manusia Indonesia yang lebih berkualitas di masa kini dan di masa-masa yang akan datang. Sebagai suatu program yang terencana dan sistematis, tentunya di dalam program pendidikan tersebut terdiri dari beberapa komponen ataupun prosedur-prosedur yang saling berhubungan. Pendidikan merupakan proses pengubahan sikap dan tata laku seseorang atau kelompok orang dalam usaha mendewasakan manusia melalui upaya pengajaran dan pelatihan (Muhibbinsyah, 2010). Pendidikan pada hakekatnya adalah usaha sadar untuk mengembangkan kepribadian dan kemampuan yang dilaksanakan baik di dalam maupun di luar sekolah dan berlangsung seumur hidup.

Mulai tahun ajaran 2013/2014, pemerintah telah menetapkan kurikulum baru yaitu Kurikulum 2013, sebagai pengganti Kurikulum Tingkat Satuan Pendidikan (KTSP). Pergantian kurikulum ini diharapkan dapat mengatasi permasalahan yang ada pada kurikulum sebelumnya dan dimaksudkan untuk menghadapi persaingan global berbasis teknologi informasi. Kurikulum 2013 merupakan Kurikulum Tingkat Satuan Pendidikan (KTSP) yang berfokus pada penguasaan pengetahuan yang kontekstual sesuai daerah dan lingkungan masing-masing. Kurikulum tersebut menitik beratkan penilaiaan hasil belajar peserta didik pada tiga ranah yaitu ranah sikap (afektif), ranah pengetahuan (kognitif), dan ranah keterampilan (psikomotorik).

Penilaian adalah suatu proses atau kegiatan yang sistematis dan berkesinambungan untuk mengumpulkan informasi tentang proses dan hasil belajar peserta didik dalam rangka membuat keputusan-keputusan berdasarkan kriteria pertimbangan tertentu. Keputusan yang dimaksud adalah keputusan tentang peserta didik, seperti nilai yang akan diberikan atau juga keputusan tentang kenaikan kelas dan kelulusan (Arifin, 2012).

Penilaian hasil belajar secara esensial bertujuan untuk mengukur keberhasilan pembelajaran yang dilakukan oleh guru dan sekaligus mengukur keberhasilan peserta didik dalam penguasaan kompetensi. Untuk itu, penilaian hasil belajar merupakan sesuatu yang sangat penting. Dalam hal ini, guru dapat melakukan refleksi dan evaluasi terhadap kualitas pembelajaran yang telah dilakukan. Apakah metode, strategi, media, model pembelajaran dan hal lain yang dilakukan dalam proses belajar mengajar itu tepat dan efektif atau sebaliknya bisa dilihat dari hasil belajar yang diperoleh peserta didik.

Sistem penilaian dan kegiatan belajar mengajar merupakan kegiatan yang saling berkaitan. Hal tersebut senada dengan pendapat Parnel (Purwanto, 2002) yang mengemukakan bahwa "Tanpa adanya penilaian, tidak akan terjadi umpan balik. Tanpa umpan balik, tidak akan diperoleh pengetahuan yang baik tentang hasil. Tanpa pengetahuan tentang hasil, tidak dapat terjadi perbaikan yang sistematis dalam belajar." Kutipan tersebut menunjukkan bahwa Penilaian merupakan komponen penting dalam penyelenggaraan pendidikan. Upaya meningkatkan kualitas pendidikan dapat ditempuh melalui peningkatan kualitas pembelajaran dan kualitas sistem penilaiannya. Keduanya saling terkait, sistem pembelajaran yang baik akan menghasilkan kualitas belajar yang baik. Kualitas pembelajaran ini dapat dilihat dari hasil penilaiannya.

Berdasarkan observasi yang dilakukan di sekolah dan hasil wawancara dengan pendidik di SMAN 3 Makassar, maka peneliti melakukan penelitian dengan tujuan untuk menganalis deskripsi hasil belajar kognitif dan hasil belajar psikomotorik peserta didik kelas XI IPA 3 SMAN 3 Makassar terkhusus pada materi fisika yang dipelajari oleh peserta didik dengan alasan yang pertama yakni hasil belajar peserta 
didik pada pembelajaran fisika di SMAN 3 Makassar terkhusus pada materi fluida satatik dan dinamik belum pernah diteliti sebelumnya, maka dari itu peneliti melakukan penelitian tersebut. Hal ini dilakukan agar pembaca dapat memperoleh pengetahuan mengenai hasil belajar peserta didik SMAN 3 Makassar pada materi fluida statik dan dinamik. Kemudian diharapkan hasil penelitian ini dapat dijadikan dasar peninjauan oleh praktisi ataupun pendidik untuk mengembangkan diri serta meningkatkan kualitas dalam melaksanakan penilaian hasil belajar peserta didik yang sesuai dengan standar penilaian yang berlaku. Adapun alasan kedua dikarenakan penerapan metode praktikum dalam pembelajaran fisika oleh pendidik dilaksanakan pada penghujung semester selama dua sampai tiga pertemuan sehingga peneliti bisa melakukan observasi untuk memperoleh data hasil belajar psikomotorik peserta didik. Selanjutnya peneliti tertarik untuk melakukan penelitian di SMAN 3 Makassar karena alat dan bahan praktikum dilaboratorium sudah cukup memadai.

Menurut Permendikbud No. 23 Tahun 2016, standar penilaian pendidikan adalah kriteria mengenai lingkup, tujuan, manfaat, prinsip, mekanisme, prosedur, dan instrumen penilaian yang digunakan sebagai dasar dalam penilaian hasil belajar peserta didik pada pendidikan dasar dan pendidikan menengah. Penilaian pendidikan merupakan proses pengumpulan dan pengolahan informasi untuk mengukur pencapaian hasil belajar peserta didik.

Iskandar (2013) menjelaskan bahwa penilaian (assesment) adalah proses pengumpulan dan pengolahan informasi untuk mengukur pencapaian peserta didik. Penilaian hasil belajar merupakan penilaian yang dilakukan secara komprehensif untuk menilai dari tahap masukan (input), proses, dan keluaran (output) pembelajaran, yang meliputi ranah sikap, pengetahuan, dan keterampilan. Penilaian tersebut menilai kesiapan peserta didik, serta proses dan hasil belajar secara utuh. Keterpaduan penilaian ketiga komponen (input-proses-output) tersebut akan menggambarkan kapasitas, gaya, dan hasil belajar peserta didik, bahkan mampu menghasilkan dampak instruksional (instructional effects) dan dampak pengiring (nurturant effects) dari pembelajaran.

Penilaian hasil belajar dalam kurikulum 2013 mengacu pada Permendikbud No. 23 Tahun 2016 tentang Standar Penilaian Pendidikan. Penilaian hasil belajar adalah kegiatan menilai peserta didik yang menekankan pada apa yang seharusnya dinilai, baik proses maupun hasil dengan berbagai instrumen penilaian yang disesuaikan dengan tuntutan kompetensi yang ada di Kompetensi Inti (KI) dan Kompetensi Dasar (KD). Kurikulum 2013 mempertegas adanya pergeseran dalam melakukan penilaian, yakni dari penilaian melalui tes (mengukur kompetensi pengetahuan berdasarkan hasil saja), menuju penilaian yang mengukur kompetensi sikap, pengetahuan, dan keterampilan berdasarkan proses dan hasil.

\section{a. Penilaian Kompetensi Sikap}

Sikap bermula dari perasaan yang terkait dengan kecenderungan seseorang dalam merespon sesuatu/objek. Sikap juga dapat diartikan sebagai ekspresi dari nilai-nilai atau pandangan hidup yang dimiliki oleh seseorang. Sikap dapat dibentuk, sehingga menjadi prilaku atau tindakan yang diinginkan. Kompetensi sikap yang dimaksud adalah ekspresi dari nilai-nilai atau pandangan hidup yang dimiliki oleh seseorang dan diwujudkan dalam prilaku.

Cakupan penilaian kompetensi sikap dalam kurikulum 2013 terbagi menjadi dua, yaitu sikap spiritual yang terkait dengan pembentukan peserta didik yang beriman, bertakwa, dan bersyukur kepada Tuhan Yang Maha Esa, dan sikap sosial yang terkait dengan pebentukan peserta didik yang berakhlak mulia, mandiri, demokratis, dan bertanggung jawab. Sikap spiritual merupakan perwujudan dari 
menguatnya interaksi vertikal denga Tuhan Yang Maha Esa, sedangkan sikap sosial merupakan perwujudan eksistensi kesadaran dalam upaya mewujudkan harmoni kehidupan. Pada jenjang SMA/MA, kompetensi sikap spiritual mengacu pada KI-1: Menerima dan menjalankan ajaran agama yang dianutnya, sedangkan kompetensi sikap sosial mengacu pada KI-2: Menunjukkan perilaku jujur, disiplin, tanggung jawab, santun, peduli, dan percaya diri dalam berinteraksi dengan keluarga, teman guru, dan tetangganya serta cinta tanah air.

Hasil belajar menurut Bloom (1976) mencakup prestsi belajar, kecepatan belajar, dan hasil afektif. Anderson (1981) sependapat dengan Bloom bahwa karakteristik manusia meliputi cara yang tipikal dari berpikir, berbuat, dan perasaan. Tipikal berpikir berkaitan dengan ranah kognitif, tipikal berbuat berkaitan dengan ranah psikomotorik, dan tipikal perasaan berkaitan dengan ranah afektif. Ranah afektif mencakup watak perilaku seperti perasaan, minat, sikap, emosi, atau nilai. Ketiga ranah tersbut merupakan karakteristik manusia sebagai hasil belajar dalam bidang pendidikan.

Tingkatan ranah afektif menurut taksonomi Karthwohl (Autumn, 2002) ada lima, yaitu: receiving (attending), responding, valuing, organization, dan characterization.

\section{b. Penilaian Kompetensi Pengetahuan}

Penilaian kompetensi pengetahuan peserta didik merupakan penilaian potensi intelektual yang terdiri dari tingkatan mengetahui, memahami, menerapkan, menganalisis, mengevaluasi, dan mencipta. Teknik penilaian kompetensi pengetahuan dapat dilakukan melalui tes tulis, tes lisan, dan penugasan. Tiap-tiap teknik tersebut dilakukan melalui insrumentasi tertentu yang relevan.

Penilaian kompetensi pengetahuan berisi tentang prilaku-prilaku yang menekankan aspek intelektual, seperti pengetahuan, pengertian, dan keterampilan berpikir. Indikator kognitif merupakan prilaku (behavior) peserta didik yang diharapkan muncul setalah melakukan serangkaian kegiatan untuk mencapai kompetensi yang diharapkan. Selain ranah afektif dan psikomotorik, hasil belajar yang perlu diperhatikan adalah dalam ranah kognitif. Dalam Taksonomi Bloom (1976) yang direvisi oleh David R. Krathwohl (2002) di jurnal Theory into Practice, aspek kognitif dibedakan atas enam jenjang yaitu remembering, understanding, applying, analyzing, evaluating, creating.

Indikator ataupun aspek kognitif yang dikembangkan dan diamati dalam penelitian ini disesuaikan dengan kompetensi dasar materi fluida statik dan fluida dinamik pada kurikulum 2013 yang terdiri dari empat aspek, yaitu mengingat (remembering), memahami (understanding), mengaplikasikan (applying), dan menganalisis (analysing).

\section{c. Penilaian Kompetensi Keterampilan}

Penilaian kompetensi keterampilan merupakan penilaian yang dilakukan terhadap peserta didik untuk menilai sejauh mana pencapaian SKL, KI, dan KD khusus dalam dimensi keterampilan. Kompetensi Inti (KI) merupakan gambaran mengenai kompetensi yang harus dipelajari peserta didik untuk suatu jenjang sekolah, kelas, dan mata pelajaran. Kompetensi Dasar (KD) merupakan kompetensi yang di pelajari peserta didik untuk suatu mata pelajaran di kelas tertentu.

Pencapaian KI dan KD pada ranah psikomotorik mencakup keterampilan pikir dan tindakan dalam ranah abstrak dan konkret. Sebagai contoh, keterampilan memecahkan masalah dalam matematika atau fisika termasuk dalam keterampilan ranah abstrak. Keterampilan melempar dan melompat dalam olahraga termasuk dalam keterampilan ranah konkret. 
Dave (1967) dalam penjelasannya mengatakan bahwa hasil belajar psikomotorik dapat dibedakan menjadi lima tahap, yaitu: imitasi, manipulasi, presisi, artikulasi, dan naturalisasi atau observasi. 1) Meniru (perception) adalah kemampuan melakukan kegiatan-kegiatan sederhana dan sama persis dengan yang dilihat atau diperhatikan sebelumnnya. 2) Menyusun (manipulating) adalah kemampuan melakukan kegiatan sederhana yang belum pernah dilihat tetapi berdasarkan pada pedoman atau petunjuk saja. 3) Kemampuan tingkat mempraktekkan (precision) adalah kemampuan melakukan kegiatan-kegiatan yang akurat sehingga mampu menghasilkan produk kerja yang tepat. 4) Kemampuan pada tingkat mengembangkan (artikulasi) adalah kemampuan melakukan kegiatan yang kompleks dan tepat sehingga hasil kerjanya merupakan sesuatu yang utuh. 5) Kemampuan pada tingkat pengamatan adalah kemampuan fundamental yang menjadi dasar utama dari pertumbuhan keterampilan praktik peseta didik. Hal ini disebabkan karena siswa yang melakukan observasi akan menggunakan seluruh alat indra untuk mengumpulkan fakta yang relevan, sehingga dapat mencari persamaan dan perbedaan serta memperoleh informasi dari objek yang sedang diamati.

Dari penjelasan di atas dapat dirangkum bahwa penilaian hasil belajar psikomotorik peserta didik dilakukan pada saat proses belajar mengajar berlangsung yaitu pada waktu peserta didik melakukan kegiatan praktikum. Adapun indikator atau aspek psikomotorik yang diamati dalam penelitian ini adalah meniru (perception), menyusun (manipulating), mengamati, mempraktekkan (precision), dan mengembangkan (articulation).

\section{B. METODE PENELITIAN}

Jenis penelitian yang dilakukan adalah penelitian deskriptif kuantitatif. Subjek penelitian adalah peserta didik kelas XI IPA 3 SMA Negeri 3 Makassar yang berjumlah 30 orang. Variabel dalam penelitian ini adalah hasil belajar fisika peserta didik. Hasil belajar fisika dalam penelitian ini adalah skor hasil belajar kognitif peserta didik dan skor hasil belajar psikomotorik peserta didik. Untuk ranah kognitif, indikator soal yang dikembangkan disesuaikan dengan kompetensi dasar materi fluida statik dan fluida dinamik pada kurikulum 2013, sedangkan untuk hasil belajar psikomotorik, peserta didik dinilai dengan menggunakan lembar pengamatan hasil belajar psikomotorik yang dilaksanakan pada saat kegiatan praktikum berlangsung.

Setelah diperoleh skor hasil belajar peserta didik baik ranah kognitif maupun ranah psikomotorik, maka dilakukan penganalisaan data tersebut. Analisis data yang dilakukan adalah dengan menggunakan analisis deskriptif. Dari analisis deskriptif tersebut diperoleh gambaran tentang skor hasil belajar kognitif peserta didik dan psikomotorik peserta didik yang kemudian ditampilkan dalam bentuk: Skor rata-rata hasil belajar, skor ideal maksimum, skor ideal minimum, skor tertinggi, skor terendah, varians, satndar deviasi, dan rentang skor.

1) Skor rata-rata dalam penelitian ini diperoleh dengan menggunaan persamaan:

$$
\bar{x}=\frac{\Sigma x}{N}
$$

Keterangan:

$\bar{x}=$ skor rata-rata peserta didik

$\Sigma x=$ jumlah skor keseluruhan peserta didik

$N=$ jumlah peserta didik 
2) Varians dalam penelitian ini diperoleh dengan menggunakan persamaan:

$$
S^{2}=\frac{\sum_{i=1}^{N}\left(x_{i}-\bar{x}\right)^{2}}{N-1}
$$

(Sudjana, 2005)

Keterangan:

$S^{2}=$ nilai varians

$x=$ skor peserta didik

$\bar{x}=$ skor rata-rata peserta didik

3) Satandar deviasi diperoleh dengan menggunakan persamaan:

$$
S=\sqrt{\frac{\sum_{i=1}^{N}\left(x_{i}-\bar{x}\right)^{2}}{N-1}}
$$

(Sudjana, 2005)

Keterangan:

$S=$ nilai standar deviasi

$x=$ skor peserta didik

$\bar{x}=$ skor rata-rata peserta didik

4) Skala penilaian hasil belajar peserta didik

a) Skala penilaian hasil belajar kognititf peserta didik yang digunakan dalam penelitian ini dapat dilihat pada Tabel 3.1.

Tabel 1. Skala Penilaian Hasil Belajar Kognititf Peserta Didik

\begin{tabular}{cc}
\hline \multicolumn{2}{c}{ Tabel Kategori } \\
\hline Interval & Kategori \\
$\mathbf{0}-\mathbf{4}$ & Sangat Rendah \\
$\mathbf{5}-\mathbf{1 0}$ & Rendah \\
$\mathbf{1 1}-\mathbf{1 6}$ & Sedang \\
$\mathbf{1 7}-\mathbf{2 2}$ & Tinggi \\
$\mathbf{2 3}-\mathbf{2 8}$ & Sangat Tinggi \\
\hline
\end{tabular}

b) Skala penilaian hasil belajar psikomotorik peserta didik yang digunakan dalam penelitian ini dapat dilihat pada 3.2.

Tabel 2. Skala Penilaian Hasil Belajar Psikomotorik Peserta Didik

\begin{tabular}{cc}
\hline \multicolumn{2}{c}{ Tabel Kategori } \\
\hline Interval & Kategori \\
$\mathbf{0}-\mathbf{4}$ & Sangat Rendah \\
$\mathbf{5}-$ & Rendah \\
$\mathbf{9 - 1 2}$ & Sedang \\
$\mathbf{1 3 - 1 6}$ & Tinggi \\
$\mathbf{1 7}-\mathbf{2 0}$ & Sangat Tinggi \\
\hline
\end{tabular}

\section{HASIL DAN PEMBAHASAN}

a. Hasil Penelitian

1) Hasil Belajar Psikomotorik Peserta Didik 
Data hasil belajar kognitif peserta didik dalam penelitian ini diperoleh melalui tes teori dengan bentuk soal pilihan ganda dan jumlah item sebanyak 27 butir soal. Adapun metode pemberian skor yang digunakan dalam tes teori tersebut adalah angka 1 untuk jawaban benar dan angka 0 untuk jawaban salah. Gambaran skor hasil belajar kognitif peserta didik pada kelas XI MIA 3 SMA Negeri 3 Makassar dapat dilihat pada Tabel 4.1.

Tabel 1. Analisis Satatistik Hasil Belajar Kognitif

\begin{tabular}{cc}
\hline Statistik & Hasil Belajar Kognitif \\
\hline Ukuran Sampel (n) & 30 \\
Skor Ideal Maksimum & 27 \\
Skor Ideal Minimum & 0 \\
Skor tertinggi & 24 \\
Skor terendah & 6 \\
Rentang skor & 18 \\
Skor rata-rata & 13,97 \\
Varians & 18,45 \\
Standar deviasi & 4,29
\end{tabular}

Berdasarkan Tabel 4.1 diketahui bahwa jumlah keseluruhan peserta didik pada kelas XI MIA 3 adalah 30 peserta didik yang menyatakan banyaknya jumlah subjek yang ditelitit dalam penelitian ini. Dari 30 subjek tersebut diketahui skor ideal maksimum, skor ideal minimum, skor tertinggi, skor terendah, varians, satndar deviasi, rentang skor, dan skor rata-rata hasil belajar kognitif peserta didik pada materi fluida statik dan fluida dinamik.

Skor hasil belajar kognitif fisika merupakan skor total yang diperoleh peserta didik pada kelas XI MIA 3 setelah diberikan tes hasil belajar kognitif fisika peserta didik yang mengacu pada indikator pencapaian hasil belajar dalam bentuk tes pilihan ganda. Skor tertinggi pada tes hasil belajar kognitif fisika yang mungkin dicapai oleh peserta didik adalah 27 skor apabila menjawab 27 soal dengan benar dan skor terendah dalam tes hasil belajar kognitif adalah 0 apabila tidak ada jawaban yang benar. Skor hasil belajar kognitif fisika peserta didik untuk skor individu tertinggi pada kelas XI MIA 3 yaitu 24 artinya peserta didik menjawab 24 soal dengan benar dan skor terendah yang didapat yaitu 6 artinya peserta didik hanya menjawab 6 butir soal dengan benar.

Skor hasil belajar kognitif peserta didik dalam penelitian ini dikategorikan berdasarkan pengkategorian hasil belajar kognitif fisika peserta didik. Pengkategorian tersebut dibuat dalam bentuk tabel distribusi frekuensi seperti pada Tabel 4.2.

Tabel 2. Distribusi Frekuenisi Berdasarkan Kategori Hasil Belajar Kognitif Peserta Didik

\begin{tabular}{cccc}
\hline Interval Skor & Kategori & Frekuensi & $\mathbf{( \% )}$ \\
$\mathbf{0 - 4}$ & Sangat Rendah & 0 & 0,00 \\
$\mathbf{6 - 1 0}$ & Rendah & 7 & 23,33 \\
$\mathbf{1 1 - 1 6}$ & Sedang & 16 & 53,33 \\
$\mathbf{1 7}-\mathbf{2 2}$ & Tinggi & 6 & 20,00 \\
$\mathbf{2 3 - 2 8}$ & Sangat Tinggi & 1 & 3,33 \\
& Jumlah & $\mathbf{3 0}$ & $\mathbf{1 0 0 , 0 0}$
\end{tabular}

Dari data pada Tabel 4.2 terlihat bahwa tidak ada peserta didik yang tergolong dalam kategori "sangat rendah". Kategori hasil belajar kognitif pada kelas XI MIA 3 tersebut memiliki frekuensi 7 peserta didik dengan persentase 23,33\% pada kategori "rendah", pada ketegori "sedang" kelas tersebut 
memiliki frekuensi 16 peserta didik dengan persentase 53,33\%, frekuensi 6 peserta didik dengan persentase 20,00\% yang tergolong dalam kategori "tinggi", dan frekuensi 1 peserta didik dengan persentase sebesar 3,33\% yang tergolong dalam kategori "sangat tinggi".

Distribusi frekuensi rata-rata hasil belajar kognitif peserta didik pada kelas XI MIPA 3 dapat dilihat pada Gambar 4.1.

Gambar 4.1 Histogram Klasifikasi Hasil Belajar Kognitif Peserta Disik Berdasarkan Tabel Distribusi

Frekuensi

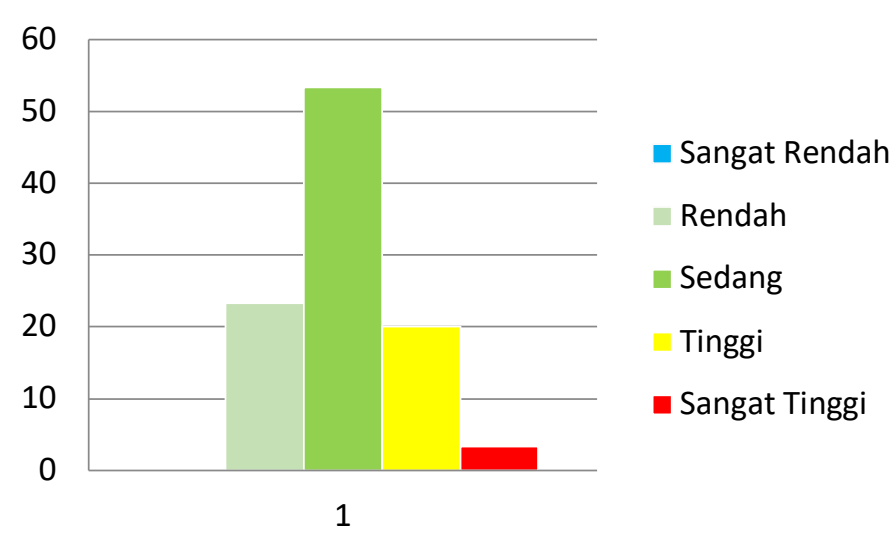

\section{2) Hasil Belajar Psikomotorik Peserta Didik}

Penilaian hasil belajar psikomotorik fisika peserta didik diamati dan dinilai berdasarkan instrumen lembar pengamatan hasil belajar psikomotorik peserta didik dengan berpedoman pada rubrik penilaian. Pengamatan hasil belajar psikomotorik peserta didik pada penelitian ini meliputi 5 aspek penilaian yaitu meniru, menyusun, mengamati, mempraktekkan dan mengembangkan. Pengamatan hasil belajar psikomotorik peserta didik selama pembelajaran dilakukan oleh 2 orang pengamat.

Gambaran skor hasil belajar psikomotorik peserta didik pada kelas XI MIA 3 SMA Negeri 3 Makassar selama proses pembelajaran berlangsung terkhusus pada kegiatan praktikum dapat dilihat pada Tabel 4.3.

Tabel 3. Analisis Statistik Hasil Belajar Psikomotorik

\begin{tabular}{cc}
\hline Statistik & Hasil Belajar Psikomotorik \\
\hline Ukuran Sampel (n) & 30 \\
Skor Ideal Maksimum & 20 \\
Skor Ideal Minimum & 0 \\
Skor tertinggi & 20 \\
Skor terendah & 14 \\
Rentang skor & 6 \\
Skor rata-rata & 16,46 \\
Varians & 2,67 \\
Standar deviasi & 1,63 \\
\hline
\end{tabular}

Berdasarkan Tabel 4.3 diketahui bahwa jumlah peserta didik pada kelas XI MIA 3 adalah 30 peserta didik yang menyatakan banyaknya jumlah subjek yang diteliti. Dari 30 subjek tersebut diketahui skor ideal maksimum, skor ideal minimum, skor tertinggi, skor terendah, varians, satndar deviasi, rentang skor, dan skor rata-rata hasil belajar kognitif peserta didik pada materi fluida statik dan fluida dinamik. 
Skor hasil belajar psikomotorik peserta didik merupakan skor yang diperoleh peserta didik selama kegiatan pembelajaran berlangsung yang berpedoman pada rubrik penilaian hasil belajar psikomotorik peserta didik. Ada 5 poin penilaian yang dikembangkan dalam penelitian ini, dengan total 25 rubrik penilaian hasil belajar psikomotorik peserta didik. Tiap 1 rubrik yang muncul atau dilakukan oleh peserta didik memiliki rentang poin $(0-4)$ sehingga skor tertinggi yang mungkin dicapai adalah 20 poin, apabila peserta didik mampu melakukan kegiatan sesuai dengan petunjuk yang telah disusun dalam bentuk Lembar Kerja Peserta Didik (LKPD) dan skor terendah adalah 0 apabila peserta didik tidak bisa melakukan kegiatan sesuai dengan petunjuk yang telah disediakan. Skor hasil belajar psikomotorik peserta didik untuk skor individu tertinggi yaitu 20 poin dan skor terendah yang diperoleh yaitu 14 poin.

Skor hasil belajar psikomotorik peserta didik dapat dikategorikan berdasarkan pengkategorian hasil belajar psikomotorik fisika peserta didik. Pengkategorian tersebut dibuat dalam bentuk tabel distribusi frekuensi seperti pada Tabel 4.4.

Tabel 4.4 Distribusi Frekuenisi Berdasarkan Kategori Hasil Belajar Psikomotorik Peserta Didik

\begin{tabular}{|c|c|c|c|}
\hline Interval Skor & Kategori & Frekuensi & $\%$ \\
\hline $0-4$ & Sangat Rendah & 0 & 0,00 \\
\hline $5-8$ & Rendah & 0 & 0,00 \\
\hline $9-12$ & Sedang & 0 & 0,00 \\
\hline $13-16$ & Tinggi & 16 & 53,33 \\
\hline $17-20$ & Sangat Tinggi & 14 & 46,67 \\
\hline \multicolumn{2}{|c|}{ Jumlah } & 30 & 100,00 \\
\hline
\end{tabular}

Dari data pada Tabel 4.4 terlihat bahwa tidak ada peserta didik yang tergolong dalam kategori sangat rendah, rendah, dan sedang. Kelas XI MIA 3 tersebut memiliki frekuensi 16 peserta didik dengan persentase 53,33\% pada kategori tinggi, dan pada ketegori sangat tinggi kelas tersebut memiliki frekuensi 14 peserta didik dengan persentase $46,67 \%$.

Distribusi frekuensi rata-rata hasil belajar psikomotorik peserta didik pada kelas XI MIA 3 dapat dilihat pada Gambar 4.2

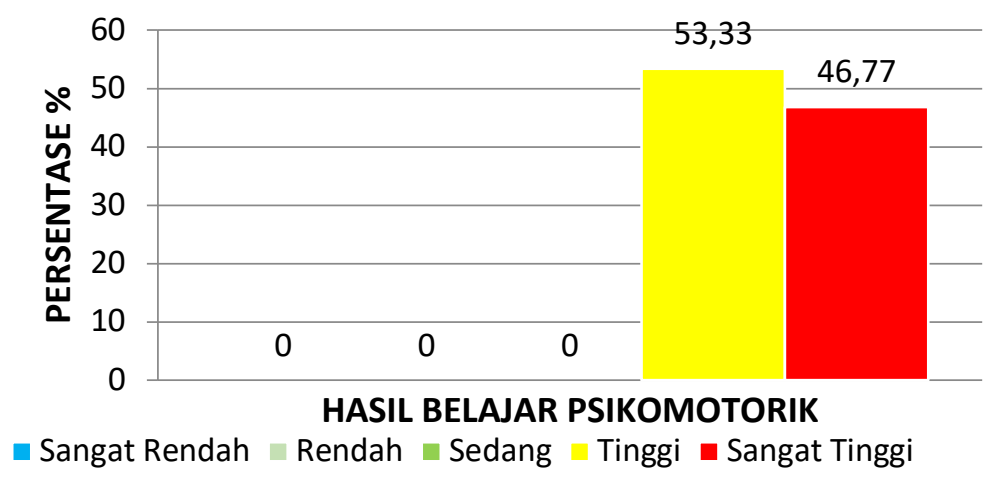

Gambar 4.2 Histogram Klasifikasi Hasil Belajar Psikomotorik Peserta Disik Berdasarkan Tabel Distribusi Frekuensi

\section{b. Pembahasan}


Penelititan ini bertujuan untuk memperoleh informasi mengenai deskripsi hasil belajar kognitif dan psikomotorik peserta didik pada kelas XI MIA SMA Negeri 3 Makassar pada mata pelajaran fisika materi fluida stasik dan fluida dinamik. Materi yang diajarkan oleh pendidik atau guru matapelajaran fisika mengacu pada revisi Kurikulum 2013 sebagai acuan dalam pembuatan Rencana Pelaksanaan Pembelajaran (RPP) dan bahan ajar berupa Lembar Kerja Peserta Didik (LKPD). Pembahasan mengenai hasil belajar fisika peserta didik baik ranah kognitif maupun ranah psikomotorik, akan dijelaskan sebagai berikut.

1) Hasil Belajar Kognitif Peserta Didik

Ranah kognitf berisi tentang prilaku-prilaku yang menekankan aspek intelektual, seperti pengetahuan, pengertian, dan keterampilan berpikir. Indikator kognitif merupakan prilaku (behavior) peserta didik yang diharapkan muncul setalah melakukan serangkaian kegiatan untuk mencapai kompetensi yang diharapkan. Selain ranah afektif dan psikomotorik, hasil belajar yang perlu diperhatikan adalah dalam ranah kognitif.

Untuk mengetahui deskripsi hasil belajar kognitif peserta didik, maka peserta didik diberikan soal tes bentuk pilihan ganda sebanyak 27 soal. Tes tersebut diberikan setelah peserta didik mengikuti proses pembelajaran dalam kelas. Menurut (Anderson, dkk. 2010) terdapat beberapa indikator atau domain dalam kemampuan kognitif yang harus dimiliki peserta didik yaitu (C1), memahami (C2), mengaplikasikan (C3), menganalisis (C4), mengevaluasi (C5), dan mencipta (C6). Sesuai dengan indikator yang telaha dikembangkan berdasarkan kompetensi dasar, maka dalam penelitian ini hanya mengambil empat indikator yaitu mengetahui, memahami, mengaplikasikan, dan menganalisis.

Setelah dilaksanakannya proses pembelajaran, peserta didik lebih memahami materi fluida statik dan fluida dinamik. Hal tersebut ditunjukkan adanya perubahan dalam diri peserta didik yang mencakup perubahan pengetahuan dan keterampilan setelah melalui proses belajar, sesuai pendapat Winkel dalam Purwanto (2011) bahwa hasil belajar adalah perubahan yang mengakibatkan manusia berubah dalam aspek pengetahuan dan tingkah lakunya. Aspek perubahan itu mencakup ranah kognitif, dan psikomotorik sebagaimana yang diamati dan diukur dalam penelitian ini.

Data hasil belajar kognititf fisika peserta didik dalam penelitian ini diperoleh dari data skor tes hasil belajar kognititf fisika peserta didik yang diberikan di akhir pembelajaran (posttest) berupa tes objektif sebanyak 27 butir soal. Skor rata-rata tes hasil belajar kognititf fisika peserta didik kelas XI MIA 3 SMA Negeri 3 Makassar sebesar 13,97 dengan standar deviasi sebesar 4,29. Data yang diperoleh tersebut menunjukkan bahwa skor rata-rata hasil belajar kognitif peserta didik hanya berada pada kategori sedang.

\section{2) Hasil Belajar Psikomotorik Peserta Didik}

Ranah psikomotorik adalah ranah yang berhubungan dengan aktivitas fisik, misalnya berlari, melompat, melukis, menari, memukul dan sebagainya. Menurut Mardapi (2003), keterampilan psikomotorik ada enam tahap yaitu: gerakan refleks, gerakan dasar, kemampuan perseptua, gerakan fisik, gerakan terampil, dan komunikasi nondiskutif. Gerakan refleks adalah respon motorik atau gerak tanpa sadar yang muncul ketika bayi lahir. Gerakan dasar adalah gerakan yang mengarah pada keterampilan komplek yang khusus. Kemampuan perseptual adalah kombinasi kemampuan kognitif dan motorik atau gerak. Kemampuan fisik adalah kemampuan untuk mengembangkan gerakan terampil. Gerakan terampil adalah gerakan yang memerlukan belajar, seperti keterampilan dalam olah 
raga. Komunikasi nondiskutif adalah kemampuan berkomunikasi dengan gerakan. Penilaian psikomotorik dapat dilakukan dengan menggunakan lembar observasi atau lembar pengamatan. Lembar observasi sebagai alat penilaian banyak digunakan untuk mengukur tingkah laku individu ataupun proses terjadinya suatu kegiatan yang dapat diamati. Dengan kata lain, lembar observasi dapat mengukur atau menilai hasil dan proses belajar psikomotorik. Misalnya tingkah laku peserta didik ketika melaksanakan kegiatan praktikum, kegiatan diskusi dan pratisipasi peserta didik dalam simulasi.

Penilaian hasil belajar psikomotorik fisika peserta didik dalam penelitian ini dilakukan dengan menggunakan lembar penilaian hasil belajar psikomotorik yang dikembangkan sendiri oleh peneliti. Hasil belajar psikomotorik fisika peserta didik erat kaitannya dengan keterampilan peserta didik dalam melakukan kegiatan praktikum di laboratorium atau kelas.

Untuk mengetahui deskripsi hasil belajar psikomotorik peserta didik maka digunakan lembar pengamatan. Lembar pengamatan digunakan peneliti ketika peserta didik melakukan kegiatan praktikum di kelas. Menurut Sutrisno Hadi (1986) dalam Sugiyono (2013) bahwa, observasi merupakan suatu proses yang kompleks, suatu proses yang tersusun dari berbagai proses biologis dan psikologis. Dua diantara yang terpenting adalah proses-proses pengamatan dan ingatan.

Adapun indikator-indikator yang dikembangkan dalam penelitian ini adalah keterampilan meniru (perception): kemampuan merangkai alat percobaan, keterampilan menyusun (manipulating): menggunakan alat percobaan, keterampilan mengamati, keterampilan melakukan dengan prosedur (precision) mempraktekkan, dan keterampilan melakukan dengan baik dan tepat (articulation): mengembangkan.

Berdasarkan hasil penilaian 2 orang pengamat menggunakan lembar pengamatan hasil belajar psikomotorik peserta didik, diketahui bahwa skor rata-rata hasil belajar psikomotorik peserta didik di kelas XI MIA 3 SMA Negeri 3 Makassar sebesar 16,41 dengan standar deviasi sebesar 1,63. Data yang diperoleh tersebut menunjukkan bahwa skor rata-rata hasil belajar kognitif peserta didik berada pada kategori tinggi.

Dari penyajian data secara keseluruhan menunjukkan bahwa hasil belajar kognitif peserta didik berada pada nilai rata-rata 13,97 dengan standar deviasi sebesar 4,29 atau berada pada kategoti sedang dan hasil belajar psikomotorik peserta didik berada pada nilai rata-rata 16,46 dengan standar deviasi sebesar 1,63 atau berada pada ketegori tinggi. Hal ini didukung oleh penelitian yang dilakukan oleh Ocatviana Rosa (2015) dalam jurnal yang berjudul "Analisis Kemampuan siswa Kelas X pada Ranah Kognitif, Afektif dan Psikomotori” menyimpulkan bahwa kemampuan rata-rata peserta didik pada ranah kognitif materi optik berada pada kategori cukup, sedangkan kemampuan rata-rata peserta didik pada ranah psikomotorik materi optik berada pada kategori tinggi.

Berdasarkan analisis diatas dapat diketahui skor rata-rata hasil belajar kognitif dan skor rata-rata hasil belajar psikomotorik peserta didik. Hasil belajar kognitif peserta didik yang kurang baik disebabkan karena kurangnya antusias peserta didik dalam mengikuti pembelajaran teori di kelas, berbeda kondisi ketika mengikuti pembelajaran praktikum di laboratorium. Ketika peserta didik melaksanakan pembelajaran teori di kelas, banyak dari mereka yang melakukan hal-hal yang seharusnya tidak dilakukan seperti berbicara dengan teman, tidur, memainkan handphone, dan kegiatan-kegiatan lain, yang intinya tidak memperhatikan pendidik ketika menyampaikan materi pembelajaran. Oleh karena itu tidak heran jika hanya sebagian peserta didik saja yang aktif dan mau bertanya pada pendidik tentang materi pembelajaran yang disampaikan. Hal tersebut mengakibatkan 
peserta didik kurang mampu mengerjakan soal dengan benar. Proses pembelajaran yang kurang menarik dan penyampaian materi yang masih dominan menggunakan media papan tulis diduga menjadi faktor utama yang menyebabkan kurangnya antusias peserta didik dalam mengikuti proses pembelajaran di kelas.

\section{KESIMPULAN}

Skor rata-rata hasil belajar kognitif peserta didik pada kelas XI MIA 3 SMA Negeri 3 Makassar pada materi fluida statik dan fluida dinamik adalah 13,97 dengan standar deviasi sebesar 4,29 atau berada pada kategori sedang. Sedangkan skor rata-rata hasil belajar psikomotorik peserta didik pada kelas XI MIA 3 SMA Negeri 3 Makassar pada materi fluida statik dan fluida dinamik secara keseluruhan adalah 16,46 dengan standar deviasi sebesar 1,63 atau berada pada kategori tinggi.

\section{REFERENSI}

Anderson, L. W. (1981). Assessing Affective Characteristic in the Schools. Boston: Allyn and Bacon. Arifin, Z. (2012). Evaluasi Pembelajaran. Bandung: PT. Remaja Rosdakarya.

Bloom, B. S. (1976). Taxonomy of Educational Objectives. New York: David McKay.

Dave, R. (1967). Taxonomy of Educational Objectives and Achievement Testing. London: University of London Press.

Iskandar, H. (2013). Model Pengembangan Penilaian Hasil Belajar. Jakarta: Kementrian Pendidikan dan Kebudayaan Direktorat Jenderal Pendidikan Menengah Direktorat Pembinaan SMA. Diakses dari https://kelaskita.com/media/static/model penilaian hasil belajar.pdf pada tanggal 3 Mei 2018.

Krathwohl, D. R (2002). A Revision of Bloom's Taxonomy: An Overview. Theory into practice Teaching and Assessing. Journal Theory Into Prctice.

Krathwohl, D. R., \& Anderson, L. W. (1961). A Taxonomy for Learning, Teaching and Assessing. New York: Longman.

Oktaviani, R.F. (2015). Analisis Kemampuan Siswa Kelas X pada Ranah Kognitif, Afektif dan Psikomotorik. Jurnal Fiska dan Pendidikan Fisika Vol 1, No 2 (2015).

Popham, W. (1995). Classroom Assessment. Boston: Allyn and Bacon.

Purwanto, N. (2002). Prinsip-prinsip dan Teknik Evaluasi Pengajaran. Bandung: PT Remaja Rosdakarya.

Sudjana, D. (2006). Evaluasi Program Pendidikan Luar Sekolah. Bandung: PT Remaja Rosdakarya.

Syah, Muhibbin. (2010). Psikologi Pendidikan (Dengan Pendekatan Baru). Bandung: PT. Remaja Rosdakarya. 